\title{
MANAJEMEN PENDIDIKAN ISLAM DAN PENYIAPAN BONUS DEMOGRAFI INDONESIA TAHUN 2045
}

\author{
Ahmad Khoiron Minan ${ }^{1}$ \\ ${ }^{1}$ Universitas Islam Negeri Sunan Kalijaga, Yogyakarta, Indonesia \\ minansendang@gmail.com
}

\begin{abstract}
Population growth that continues to change needs an effort in preparing human resources. This preparation is needed to be able to compete in the era of demographic bonuses. In this paper we will mention the demographic bonus explanation, Islamic education management and efforts to prepare human resources in the era of demographic bonus. The demographic bonus is an explosion of the productive age population so that the nonproductive age dependency number results in an opportunity to increase the rate of economic growth. Management of Islamic education is the activity of managing education which is carried out effectively and efficiently in accordance with the stated objectives. The effort of Islamic education management in preparing human resources is to revisit the process of Islamic education in order to produce productive human beings who are ready to compete in the era of demographic bonuses, by carrying out management functions.
\end{abstract}

Key words: management, islamic education, demographic bonus

\begin{abstract}
ABSTRAK
Pertumbuhan penduduk yang terus mengalami berubahan perlu adanya upaya dalam menyiapkan sumber daya manusia. Penyiapan ini dibutuhan agara mampu bersaing di era bonus demografi. Dalam tulisan ini akan menyinggung tentang penjelasan bonus demografi, manajemen pendidikan Islam dan upaya penyiapan sumber daya manusia di era bonus demografi. Bonus demografi merupakan ledakan penduduk usia produktif sehingga angka ketergantungan usia non produktif yang berakibat peluang peningkatan laju pertumbuhan ekonomi. Manajemen pendidikan Islam adalah kegaiatan pengelolaan pendidikan yang dilakukan secara efektif dan efisien sesuai dengan tujuan yang telah ditetapkan. Upaya manajemen pendidikan Islam dalam penyiapan sumber daya manusia yaitu mengkosep kembali proses pendidikan Islam dalam rangka menghasilkan manusiamanusia produktif yang siap berkompetisi dalam era bonus demografi, dengan melaksanakan fungsi-fungsi manajemen.
\end{abstract}

Kata Kunci: manjemen, pendidikan islam, bonus demografi

\section{PENDAHULUAN}

Indonesia sebagai salah satu negara terbesar keempat didunia dengan total penduduk sekitar 260 juta jiwa atau sekita 3,6 persen dari jumlah penduduk total dunia (Andriani, Pitoyo, and Pangaribowo 2018, 2). Sudah barang tentu memiliki tantangan tersendiri dalam dalam upaya pemanfaatan sumber daya manusia. Upaya yang dilakukan pemerintah salah satunya dengan membuka lapangan pekerjaan yang luas dan memberikan pelayanan pengembangan usaha mikro dan ekonomi kreatif. Usaha ini dilakukan guna untuk menyerap sebesar-besarnya potensi sumber daya masyarakat yang ada. Potensi sumber daya dalam suatu negara setidaknya harus melihat dua aspek penting yaitu pendidikan sebagai penentu kualitas dan jumlah usia produktif yang dimiliki dalam sebuah negara. Ini kemudian menjadi 
sebuah pertanyaan apakah dengan jumlah penduduk yang sedemikin besar apakah Indonesia mempunyai dua aspek penting tersebut. Kualitas sumber daya manusia menjadi sebuah tolak ukur maju dan mundurnya sebuah negara, karena dengan adanya sumber daya yang baik, dari segi etos kerja, soft skill dan life skil akan dapat menggerakan roda perekonomian suatu negara kearah kemakmuran dan kesejahteraan. Akan tetapi apabila kulitas SDM rendah, maka bukan tidak mungkin negara akan tenggelam dalam persaingan global dan menyebabkan negara berada diambang kehancuran. (Muna, n.d., 68).

Jika dilihat dari prediksi jumlah usia produktif yaitu antara (15-64 Tahun) Indonesia memiliki setidaknya 183 Juta jiwa atau sekitar 67 persen dari seluruh total penduduk Indonesia, yang artinya penduduk usia produktif jauh lebih besar dari usia non produktif, sehingga rasio ketergantungan usia non produktif lebih kecil. Inilah yang kemudian disebut sebagai bonus demografi, (Satiti 2019, 78).

Oleh karena itu, bonus demografi mampu menjadi anugrah yang besar apabila pemerintah mampu memanfaatkannya dengan cara meningkatkan kualitas SDM melalui pendidikan, pelatihan, kesehataan dan penyediaan lapangan pekerjaan yang luas sebagai investasi pasca bonus demografi. (Konadi and Iba 2008, 18).

Akan tetapi bonus demografi dapat menjadi sebuah bencana demografi apabila tidak mampu dimanfaatkan dengan baik oleh pemerintah yang berakibat pada melonjaknya jumlah pegangguran dan kegagalan negara dalam berinvestasi pasca bonus demografi. Menanggulangi ancaman kegagalan pemanfaatan bonus demografi, upaya yang paling efektif adalah dengan peningkatan kualitas sumber daya manusia melalui pendidikan.

Eksistensi sebuah negara dalam meningkatkan kualitas sumber daya manusia dilihat dari bagaimana proses pendidikannya sebagai salah satu faktor dalam menyiapakan generasi muda yang mampu bersaingan dengan negara lain. kualitas sumber daya manusia menjadi persyaratan mutlak dalam tolak ukur kemajuan sistem pendidikan nasional. (Indarsih 2019, 54). Dalam rangka meningkatkan sumber daya manusia unggul, kompetitif dan berkarakter, pemerintah melalui Kemendikbud terus berupaya untuk mengembangkan pendidikan dan kebudayaan dengan merujuk pada Nawacita yang tertuang dalam Rancangan Pembangunan Jangka Menegah Nasional (PRJMN 2015-2019), yakni peningkatan kualitas hidup, revolusi karakter bangsa, peningkatan produktivitas rakyat dan daya saing di pasar internasional serta memperteguh kebhinekaan dan memperkuat restorasi sosial Indonesia. (Fakhriyani 2017, 76). Upaya yang dilakukan oleh pemerintah diatas sebagai cara untuk menigkatkan kualitas sumber daya manusia dalam rangka menjawab tantangan bonus demografi. 
Pembinaan pendidikan Islam sebagai tanggung jawab Kementrian Agama selama ini masih perlu adanya langkah-langkah strategis. Sebagai upaya dalam meningkatkan kualitas sumber daya manusia, penerapan nilai-nilai Islam dalam proses pendidikan sangat diperlukan, ini dikarenakan banyak nilai-nilai keislaman sangat relevan dalam perkembangan seperti kedisiplinan waktu dan profesionalisme. (Ekonomi et al., n.d., 48). Penarapan nilai-nilai pendidikan Islam sebagai salah satu upaya pengingkatan kualitas sumber daya manusia perlu adanya manajemen yang baik dalam rangka pengimplementasian, dimulai dari perencanaan, pengorganisasian, pelaksanaan dan pengawasan dalam proses pendidikan Islam.

Dari beberapa hal yang telah dipaparkan oleh penulis, perlu adanya pembahasan lebih lanjut tentang bagaimana upaya manajemen pendidikan Islam dalam penyaiapan bonus demografi Indonesia tahun 2045. Ini dikarnakan perlunya manajemen yang tepat dalam mengkonsep kurikulum pendidikan dalam menghadapi tantangan bonus demografi, dengan harapan penulisan ini mampu menjadi gambaran awal mengenai upaya lembaga pendidikan Islam untuk menjaga lembaganya dengan baik dengan pemaparan mengenai beberapa permasalah yang harus dihadapi dan bagaimana solusi untuk menghadapinya.

\section{Bonus Demografi}

Bonus Demografi merupakan sebuah istilah dalam ilmu kependudukan (demografi) yang selalu dikaitkan dengan angka ketergantungan (Dependency Rasio). Angka ketergantungan adalah perbandingan antara jumlah penduduk usia produktif (15-64 Tahun) dangan usia non produktif (0-15 Tahun dan 64+ Tahun) dikalikan dengan 100. Angka ketergantungan menggambarkan berapa banyak orang usia non produktif yang ditanggung oleh kelompok usia produktif. Sebagai contoh angka ketergantungan Indonesia sekitar 52, artinya setiap 100 penduduk usia produktif indonesia menaggung sekitar 52 orang usia non produktif. (Falikhah 2017, 92).

Bonus Demografi adalah fenomena yang terjadi karena peningkatan usia produktif akibat penurunan kelahiran yang terjadi dalam jangka panjang, sehingga menurunkan proporasi penduduk muda yang memungkinkan angka ketegantungan dari usia muda dan tua akan berkurang, sehingga sumber daya usai produktif mampu dialihakan kegunaanya untuk memacu pertumbuhan ekonomi dan peningkatan kesejahteraan. (Fakhriyani 2017, 79). Artinya dalam masa bonus demografi usia produktif akan jauh lebih besar jika dibandingkan dengan usia non produktif. Populasi usia produktif inilah yang kemudian akan 
menjadi Golden Generation dalam menghadapi bonus demografi mulai tahun 2010 dan puncaknya akan terjadi pada tahun 2045.

Secara historis, tanda-tanda munculnya bonus demografi di Indonesia dimulai pada awal tahun 1990-an melalui keberhasilan program Keluarga Berencana (KB). Asumsi yang dibangun ketika populasi penduduk kelebihan kapasitas (overload) berbading lurus dengan kesejahteraan masyarakat dalam hal ini kemiskinan, hal ini dikarenakan beban negara terhadap penduduk akan jauh lebih besar. Oleh sebab itu dalam upaya untuk memperbaiki kualitas hidup masyarakat sekaligus mengurangi kemiskinan yang tujuannya untuk mengurangi beban ekonomi negara, maka perlu adanya pembatasan angka kelahiran. Program KB yang dicanangkan pada masa Orde Baru diimplementasikan ketingkat desa melalui posyandu dan imunisasi. Keberhasilan program KB selama kurang lebih tiga puluh tahun mampu menggeser anak-anak usia remaja (dibawah 15 Tahun), yang biasannya besar dan berat dibagian bawah dari pramida penduduk Indonesia kebagian piramida yang lebih tinggi diatasnya yaitu usia 15 tahun keatas atau pada usia 15-64 tahun. Keberhasilan tersebut berakibat pada perubahan struktur kependudukan, yang kemudian meyebabkan tangungan usia produktif kepada usia non produktif menjadi lebih ringan. (Jati 2015,4)

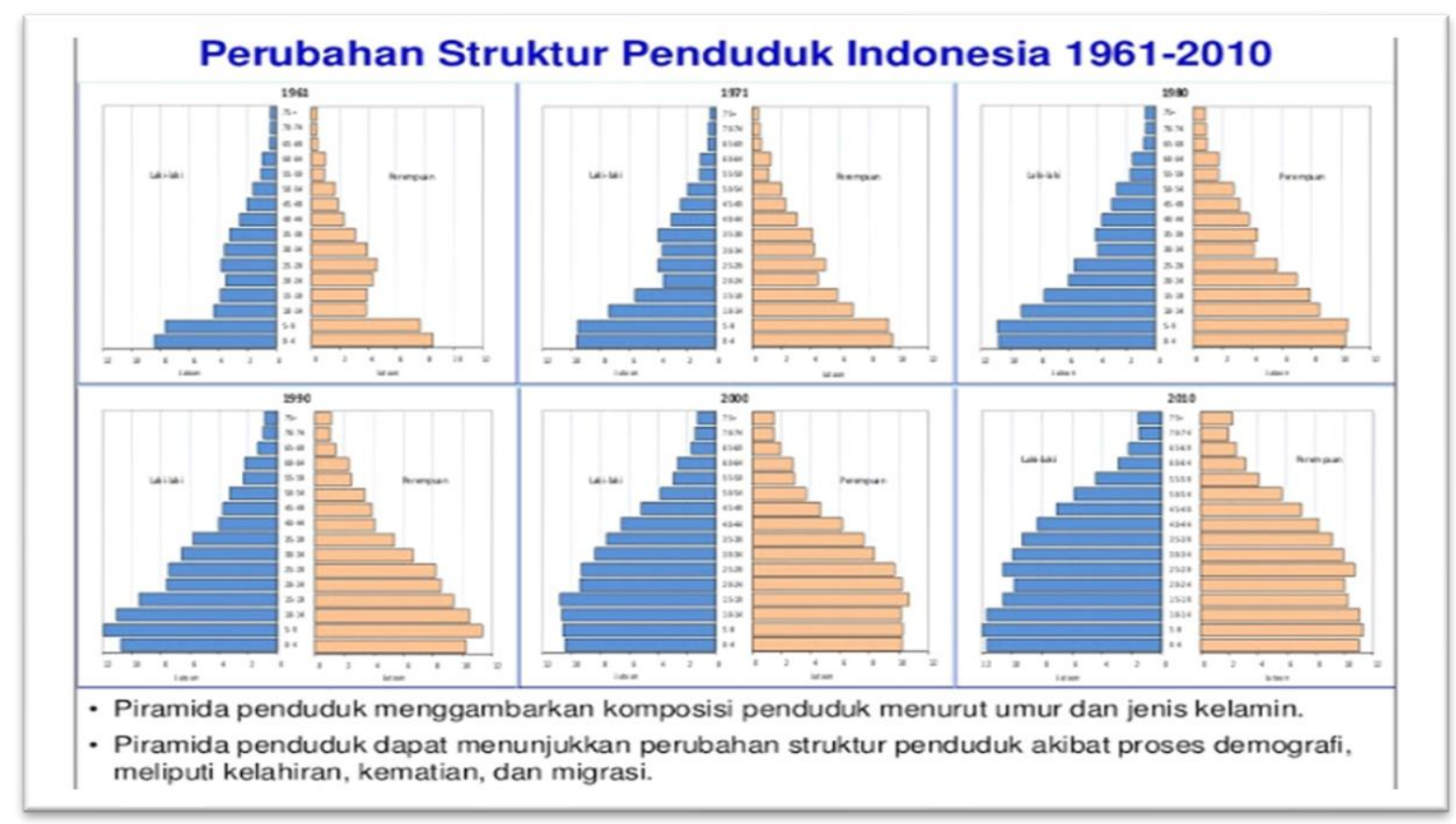

Gambar 1: Piramida Struktur Penduduk Tahun 1961-2010

Gambar piramida struktur kependudukan menujukan perubahan angka yang cukup signifikan pasca kemerdekaan. Angka kelahiran tebilang cukup tinggi yang membuat rasio 
ketergantungan usia non produktif masih cukup tinggi, yang artinya beban pemerintah dalam pemerataan kesejahteraan masih sangat berat, dikarenaka minimnya sumber daya manusia dalam hal ini usia produktif. Struktur kependudukan pada tahun-tahun selanjutnya masih sama, yang artinya rasio kelahiran masih cukup tinggi sampai pada tahun 1980. Program KB yang dicanangkan pada tahun 1990 memberikan dampak yang positif, yang kemudian mampu menggeser beban ketergantungan pada level umur atasnya, dengan cara menekan angka kelahiran. Akan tetapi pada tahun ini level ketergantungan masih cukup tinggi karena masih terdapat imbas dari angka kelahiran sebelumnya. Perubahan struktur kependudukan mulai menampakkan hasilnya diperkirakan pada tahun 2020. Ini dikarenakan penekanan angka kelahiran dibarengi dengan angka harapan hidup yang semakin tinggi, yang menandakan Indonesia telah masuk pada babak baru yaitu banus demografi. BPS memprediksi akan ada perubahan besar-besaran pada struktur kependudukan yang menujukan bahwa angka usia penduduk produktif akan meningkan pesat ditahun 20202035, seperti yang tercermin dalam gafik dibawah ini:
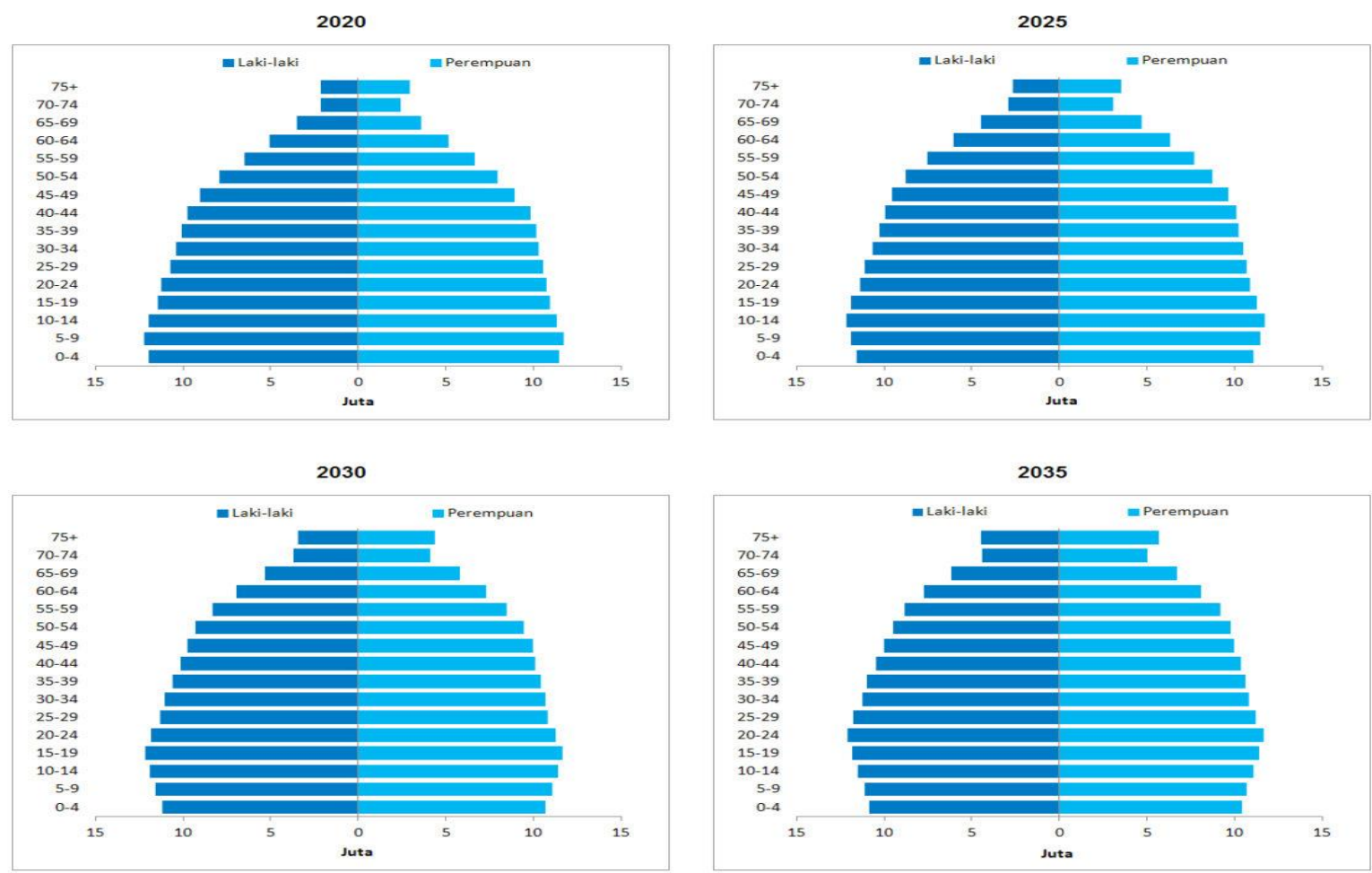

Gambar 2: Prediksi Piramida Struktur Penduduk 2020-2035

Struktuk kependudukan mulai tahun 2020 mengalami perubahan yang cukup siginifikan dengan pesatnya pertumbuhan penduduk usia produktif, hingga puncak usia produktif terjadi pada tahun 2035-2045, yang merupakan imbas dari melonjaknya angka kelahiran pada masa 20-30 tahun sebelumnya. Inilah yang kemudian dinamakan bonus demografi, 
yang mana jumlah penduduk usia produktif jauh lebih besar jika dibandingkan dengan usia non produktif, yang artinya jumlah rasio ketergantungan semakin kecil. Setelah tahun 2045 rasio ketergantungan akan kembali meningkat, kali ini akan disumbangkan oleh penduduk usia 65 keatas, oleh sebab itu pada masa bonus demografi harus dimaksimalkan, yang kemudian hasilnya mampu diinvestasikan secara produktif guna perluasan kesempatan kerja dan pertumbuhan ekonomi yang meningkat untuk mengahadapi masa pasca bonus demografi. (Sugiharto and Setiawan 2015, 6).

Ledakan penduduk usia produktif akan memberikan keuntungan ekonomi yang besar apabila memenuhi persyaratan sebagai berikut:

a. Penawaran tenaga kerja yang besar dengan kulitas yang memenuhi kebutuhan pasar tenaga kerja.

b. Meningkatkan pendapatan perkapita karena mendapat kesempatan kerja yang produktif.

c. Peningkatan peran kaum perempuan di pasar tenaga kerja karena jumlah anak yang semakin sedikit, memungkinkan perempuan memasuki pasar kerja dan membantu peningkatan pendapatan keluarga.

d. Terjadi peningkatan tabungan (saving) masyarakat yang diinvestasikan secara produktif.

e. Adanya peningakat investasi sumber daya modal manusia (human capital). (Maryati 2015, 131).

Bonus demografi dibarengi dengan peningkatan harapan hidup menurut Canning dan Sevilla telah merubah gaya hidup masyarakat disegala aspek, dalam rangka untuk menyesuaikan diri dengan kondisi demografi yang ada, adapun aspek tersebut antara lain:

a. Sikap dan perilaku masyarakat tentang pendidikan, keluarga dan peran perempuan (accounting effects dan behavoral effects)

b. Pandangan terhadap manusia lebih meningkat dan dihargai sebagai aset dari pembangunan.

c. Hasrat orang tua terhadap investasi pendidikan anak-anak, karena masyarakat meyakini akan hasilnya bagi hari tua anak-anaknya.

d. Apabila perempuan dilahirkan oleh generasi yang sudah menganut keluarga kecil, maka mereka cenderung untuk memiliki keluarga kecil juga. Berarti dalam hal ini telah terjadi perubahan pola pikir yang positif bagi masyarakat. Perempuan sudah tidak lagi hanya bekerja sebagai ibu rumah tangga saja, akan tetapi memilih untuk 
memiliki anak sedikit dan dapat masuk ke pasar kerja atau memanfaatkan Opportunity Cost. (Konadi and Iba 2008, 20).

Potensi penduduk dengan ketersediaan tenaga-tenaga usia produktf yang melimpah akan mejadi sebuah bencana demografi apabila pemerintah dan masyarakat tidak mampu dalam menanampung lonjakan usia produktif tersebut, yang artinya tidak bermanfaatnya sumber daya manusia produktif karena tidak ada alokasi dan sarana prasarana lapangan pekerjaan yang cukup untuk mengoptimalkan peran penduduk usia produktif. (Sarmita 2017, 70). Tanpa adanya persiapan yang matang bonus demografi akan menjadi bumerang bagi Indonesia dan khusunya akan beban besar bagi pemerintah terutama dalam hal ekonomi yang menyebabkan angka pengangguran akan semakin meningkat. (Muna, n.d., 69). Oleh karena itu butuh kecermatan dari pemerintah dan masyarakat, serta seluruh stakeholders agar negara kita benar-benar siap dalam menghadapi bonus demografi. (Sarmita 2017, 70). Jika pemerintah dan masyarakat mampu menafaatkan dan mempersiapkan isu bonus demografi dengan baik maka akan muncul banyak peluang-pelung yang menguntungkan bagi bangsa Indonesia.(Muna, n.d., 69) Pendidikan dipercaya sebagai salah satu cara menyiapkan generasi muda untuk mendapatkan pengetahuan dan keterampilan guna mengahadapi era bonus demografi. (Heryanah 2015, 14).

\section{Manajemen Pendidikan Islam}

Sebelum membahas tentang manajemen pendidikan Islam, terlebih dahulu kita harus mengetahui tentang konsep pendidikan Islam. Secara umum pemahaman tentang pendidikan menurut Imam Machali dapat dikategorikan menjadi dua, yaitu secara luas-tidak terbatas dan secara sempit-terbatas. Pendidikan secara luas-tidak terbatas adalah segala situasi hidup yang mempengaruhi pertumbuhan individu, yang artinya pendidikan dalam pandangan ini dimuali dari sejak manusia lahir atau berada dibumi sampai pada akhir hayat manusia, sehingga pendidikan itu berlangsung seumur hidup. Pendidikan berlangsung dalam beraneka ragam bentuk, pola dan lembaga. Pendidikan terjadi dimanapun dan tujuan akhirnya sebagai pengalaman belajar dan pertumbuhan pola pikir manusia. Sedangkan pendidikan sempit-terbatas atau sederhana adalah pengajaran yang dilakukan dalam sebuah lembaga pendidikan formal maupun non formal. Pendidikan sebagai usaha menusia untuk membina kepribadiannya sesuai dengan nilai-nilai yang ada dalam masyarakat, oleh karena itu pendidikan dalam hal ini membutuhakan peran orang dewasa agar peserta didik menjadi dewasa. (Machali and Hamid 2017, 37-38). 
Pendidikan dalam pandangan lain adalah kegiatan mentransferkan pengetahuan melalui interaksi antara pendidik dan peserta didik melalui pengarahan, pelatihan dan bimbingan untuk mencapai sebuah tujuan. (Muna, n.d., 69). Dalam perspektif ke-Indonesiaan pengertian, fungsi dan tujuan pendidikan terumuska dalam Undang-Undang Sistem Pendidikan Nasional nomor 20 Tahun 2013 pasal 1 dan 3 yaitu: pendidikan adalah usaha sadar dan terencana untuk mewujudkan suasana belajar dam proses pembelajaran agar peserta didik secara aktif mengembangkan potensi dirinya untuk memiliki kekuatan spiritual keagamaan, pengendalian diri, kepribadian, kecerdasan, akhlaq mulia, serta keterampilan yang diperlukan dirinya, masyarakat, bangsa dan Negara. (Machali and Hamid 2017, 40).

Menurut Abduh, tujuan pendidikan dalam Al-Qur'an dalah membina manusia secara pribadi dan kelompok sehingga mampu menjalankan fungsi sebagai hamba Allah dan Khalifah-Nya guna membangun dunia ini sesuai dengan konsep yang telah di tetapkan oleh Allah. (Adnan 2019, 84). Dari beberapa pengertian diatas dapat simpulkan bahwa pendidikan adalah usaha manusia dalam menyiapkan dirinya dalam menghadapi pekembangan zaman, apabila di katikan dengan Islam, maka harus disesuaikan dengan dasar ajaran Islam yaitu Al-Qur'an, Sunnah, Ijma' dan Qiyas.

Manajemen berasal dari kata "to manage" yang artinya mengatur. Secara etimologi, kata manajemen berasal dari bahasa inggris management yang mempunyai makna melatih kuda atau melangkahkan kakinya. Dalam bahasa Arab diartikan sebagai idarah, berasal dari kata adaara, yaitu mengatur. Selanjutnya dalam kata manajemen terkandung setidaknya ada tiga makna, yaitu pikiran (mind), tindakan (action) dan sikap (attiude). Al-Qur'an sebagai kitab sumber ilmu pengetahuan menyebutkan makna implisit dengan menggunakan kata AlQur'an sebagai kitab sumber ilmu pengetahuan menyebutkan makna implisit dengan menggunakan kata yudabbiru, mengandung arti mengarahkan, melaksanakan, menjalankan, mengendalikan, mengatur, mengurus dengan baik, mengkoordinasikan, membut rencana yang telah ditetapkan. Pengaturan dilakukan melalui proses dan diatur berdasarkan urutan dari fungsi-fungsi manajemen, yang artinya manajemen adalah proses untuk mewujudkan tujuan yang diinginkan. Manajemen juga merupakan ilmu dan seni dalam mengatur, mengendalikan, mengkomunikasikan dan memanfaatkan sumber daya yang ada dalam sebuah organisasi dengan memanfaatkan fungsi-fungsi manajemen yaitu Planing, Organizing, Actuating, dan Controling, agar oragnisasi dapan mencapai tujuan secara efektif dan efisien. (Husaini and Fitria 2019, 41-42). 
Manajemen pendidikan adalah gabungan dari dua kata yang memiliki satu makna yaitu manajemen dan pendidikan. Oleh sebab itu secara sederhana manajemen pendidikan adalah ilmu manajemen yang diterapkan atau dipraktekkan dalam dunia pendidikan dengan spesifikasi dan ciri khas yang ada dalam dunia pendidikan. Lebih lanjut, manajemen adalah alat-alat yang diperlukan dalam usahanya mencapai tujuan pendidikan, yang melalu serangkaian proses fungsi manajemen kemudian dikaitkan dengan bidang pendidikan. (Machali and Hamid 2017, 41-42).

Sedangkan pengertian lain menyebutkan bahwa manajemen pendidikan adalah aktivitas memadukan sumber-sumber pendidikan agar terpusat dalam usah untuk mencapai tujuan pendidikan. Definisi lain menyebutkan, manajemen pendidikan adalah suatu kegiatan atau rangkaian kegiatan yang berupa proses pengelolaan usaha kerjasama kelompok manusia dalam organisasi pendidikan, untuk mencapai tujuan pendidikan yang telah ditetapkan sebelumnya. (Adnan 2019, 85-86).

Pengertian yang telah disebutkan diatas mengindikasikan bahwa manajemen pendidikan sebagai seluruh proses kegiatan bersama dalam bidang pendidikan dengan mendayagunakan secara maksimal semua sumber daya yang ada untuk mencapai sebuah tujuan pendidikan. Hasil akhir dari manajemen pendidikan adalah produktivitas lembaga pendidikan, yang dilihat efektifitas dan efisiensi dalam sebuah lembaga. (Machali and Hamid 2017, 43-44).

Manajemen Pendidikan juga terdapat dua pengertian istilah, yaitu manajemen pendidikan Islam sebagai sebuah ilmu terapan atau praktek yang terdapat di lembaga pendidikan Islam yang artinya manajemen dalam hal ini adalah ilmu yang diterapkan pada sebuah lembaga pendidikan yang didirikan olah umat Islam. Dalam pengertian manajemen pendidikan sebagai sebuah ilmu terapan adalah dengan melaksanakan prinsip dan fungsi manajemen dalam lembaga pendidikan dengan tidak merubah konsep manajemen secara umum-skuler, kata Islam dalam praktik manajemen ini hanya pada ranah lembaga dan semangat nilai-nilai keislaman yang menjiwai aktivitas oragnisasi. Sedangkan manajemen sebagai sebuah konsep atau pemikiran tentang manajemen pendidikan dalam Islam digolongkan dalan disiplin ilmu-ilmu murni, yang lebih mengarah pada islamisasi ilmu manajemen dan memasukkan teori, prinsip dan konsep manajemen umum kedalam prinsip dan ajaran Islam yang didasarkan pada sumber-sumber hukum dan pedoman hidup Islam yaitu Al-Qu'an, Hadits, Ijma' dan Qiyas.

(Machali and Hamid 2017, 45-47). 
Manajemen pendidikan Islam pada dasarnya usaha pengeloaan yang dilakukan untuk mencapai tujuan pendidikan Islam dengan efektif dan efisien sesuai dengan apa yang telah direncanakan atau ditetapkan. Dalam melaksanakan manajemen pendidikan Islam harus dibarengi dengan

a. Motivasi bahwa setiap muslim menjalankan hidup ini adalah pengabidan kepada Allah.

b. Al-Qur'an menegaskan bahwa untuk mencapai sebuah tujuan maka perlu adanya usaha untuk mencapai tujuan tersebut, oleh sebab itu dalam melaksanakan tujuan manajemen pendidikan Islam harus didasari pada sikap keikhlasan dalam bekerja.

c. Islam selalu mangajarkan bahwa dalam hidup dan bekerja harus berorientasi pada masa depan, yang artinya dalam pengelolaan manajemen pendidikan Islam harus berorientasi dalam menjawab tantangan dan perkembangan zaman. (Adnan 2019, 93).

\section{Upaya Manajemen Pendidikan Islam Dalam Penyiapan Bonus Demografi}

Bonus demografi sebagai sebuah peluang yang dapat dimanfaatkan melalui pengembangan kualitas sumber daya manusia dengan cara pengembangan pendidikan terutama pendidikan Islam. Pendidikan sebagai usaha untuk menjawab tantang demografi juga harus dibarengi dengan pembaharuan sistem pendidikan yang berbasis tekhnologi dan informatika akibat di era globalisasi. Dalam konteks ini pendidikan harus mampu menyiapkan sumber daya manusia yang tidak hanya sebagai penerima arus global informasi melainkan harus memberikan bekal kepada peserta didik untuk dapat mengolah, menyesuaikan dan mengembangkan segala hal yang diterima dari arus informasi tersebut, yakni dalam hal ini sebagai manusia yang kreatif dan produktif. (Faisal 1995, 131).

Manusia yang kreatif dan produktif inilah yang harus menjadi visi pendidikan Islam, karena manusia seperti inilah yang kemudian didambakan dalam menjawab tantangan bonus demografi.

Pendidikan pada umumnya dan pendidikan Islam pada khususnyaa sebagai ujung tombak penyiapan sumberdaya manusia produktif di era bonus demografi, adapun ciri-ciri manusia produktif seperti yang telah sebuatkan Muchtar Buchori adalah sebagai berikut:

a. Manusia produktif adalah manusia yang mampu menerima dirinya secara ikhlas, dengan segenap kelebihan dan kekuarngan yang dimilikinya. Manusia sepertia ini tidak membuang-buang waktu untuk menikmati kelebihan yang ada pada dirinya atau menyesali kekurangannya. Dia akan lebih banyak memikirkan apa yang bisa dia lakukan dengan kelebihan dan keterbatasan yang dia miliki 
b. Manusia produktif adalah manusia yang mampu menerima lingkungannya secara ikhlas. Dia tidak menyesai dilahirkan di desa yang kurang makmur atau negara yang kurang maju, dia juga tidak laur dalam pemujaan terhadap kelebelihan yang dimiliki oleh lingkungannya. Manusia seperti ini mencoba untuk relistik dalam menyikapi lingkungan, yang kemudian dia mampu untuk melihat peluang-peluang dan potensipotensi yang ada disekitarnya.

c. Manusia produktif adalah manusia yang peka terhadap kebutuhan-kebutuhan yang ada pada zamannya. Tanpa kepekaan terhadap lingkungan, tidak mungkin baginya untuk bisa menghasilkan sesuatu yang berarti bagi lingkungnnaya. Oleh sebab itu dengan kepekaan tersebut manusia produktif tidak hanya menghasilkan saja, akan tetapi benar-benar bermanfaat dan relevann dengan tempat, waktu dan lingkungannya.

d. Manusia produktif adalah manusia yang merasa mampu bekerja atau berkarya dan merasa mengenal serta menguasai metode-metode kerja yang terdapat dalam berbagai bidang garapannya. Kepercayaan dalam menguasai bidang yang garapannya inilah yang kemudian menjadikan manusa tersebut produktif, akan tetapi yang perlu diingat bahwa produktivitas adalah fungsi kerja dan maniferstasi dari dorongan bererja dari diri seseoranglah yang dinamakan produktif. (Buchari 1994, 75).

Dalam konsep manajemen pendidikan Islam, fungsi manajemen sebagai perencana (planing) harus merencana prosedur pendidikan yang tidak hanya terfokus pada penyiapan sumber daya manusia yang siap pakai saja, akan tetapi berusaha menyiapkan sumber daya yang mampu menerima serta menyesuaikan dan mengembangkan arus perubahan yang terjadi dalam lingkungan dengan melestarikan nilai-nilai luhur dan memperbaiki penyimpangan yang diakibatkan oleh pengaruh era globalisasi. (Natta 2003, 99).

Bonus demografi sebagai sebuah fenomena yang luar biasa, pendidikan harus mampu memberikan nilai lebih dalam rangka penyiapan sumber daya manusia, oleh sebab itu harus ada standar dalam proses pendidikan terutama pendidikan Islam. Jika mengacu pada Standar Pendidikan Nasional, maka setidaknya ada sepuluh komponan dalam pendidikan yang terdiri dari visi dan misi, tujuan, kurikulum, proses belajar mengajar, pendidikan, peserta didik, manajemen, sarana prasarana, pembiayaan, sistem komunikasi, evaluasi, lingkungan dan jaringan komunikasi (Mengacu pada Badan dan Akreditasi Nasional Perguruan Tinggi 
(BAN-PT). Akan tetapi dalam menjawab tantangan bonus demografi perlu adanya paradigma baru dalam pendidikan, paradigma baru tersebut antara lain sebagai berikut:

Pertama, dari segi visi dan misi, paradigma baru pendidikan harus diarahkan pada upaya penyiapan sumber daya manusia di masa mendatang, agar mampu bersaing di era bonus demografi. Dalam konteks pendidikan Islam yaitu dengan mentransformasikan ilmu-ilmu keislaman yang di sesuaikan dengan kebutuhan zaman yang hasil akhirnya melahirkan ilmuilmu baru yang sesuai dengan zaman dan berlandaskan konsep agama Islam. Kedua, dari segi tujuan, pendidikan tidak hanya tertumpu pada pemberian pengetahuan yang bersifat kognitif (to know), akan tetapi harus disertai dengan pengamalan atau penerapan (to do), mengint]ernalisasi (to be) dan menggunakan bagi kepentingan masyarakat (to life together). Konteks dalam pendididkan Islam yaitu dalam proses pendidikan tidak hanya proses pembelajaran di kelas melainkan harus menggunakan praktikum, magang atau kerja sosial. Selain itu pendidikan Islam berupaya untuk membangun manusia secara utuh kepribadiannya meliputi aspek fisik, akal, iman, kejiwaan, akhlaq, keindahan dan sosial kemasyarakatan, sehingga hasil akhirnya adalah pribadi yang dalam dirinya beriman sepenuhnya kepada Allah S.W.T., dalam praktik sosial menjauhi sifat hedonis dan dalam praktik ekonomi menjauhi sistem kapitalis.

Ketiga, dari segi kurikulum, kurikulum sebagai sebuah acuan dalam pendidikan tidak hanya diatas kertas, melainkan harus dijalankan dalam proses pembelajaran yang sesuaikan dengan perkembangan zaman, dalam lembaga Islam selain kurikulum harus sesuai dengan visi dan misinya, tetapi juga harus menyesuaikan tantangan zaman yang dihadapi. Keempat, dari segi pendidik, dalam paradigma baru pendidik bukan lagi sebagai satu-satunya sumber infomasi, melainkan hanya salah satunya saja, siswa diharapkan mampu mengembangkan dan mencari informasi yang terdapat diberbagai media masa, internet dan lain sebagainya, sedangkan peran guru hanya sebagai fasilitator, infoman, motivator dan inovator yang mampu menciptakan kondisi pembelajaran yang kondusif bagi peserta didik, oleh sebab itu pendidik harus mempunyai kompetensi akademik, pedagogik, kepribadian dan sosial. Kelima, segi peserta didik, paradigma baru melihat peserta didik sebagai mitra kegiatan belajar mengajar, yang artinya peserta didik harus di perlakukan secara adil, manusiawi, egaliter, demokratis. Oleh sebab itu guru tidak bisa memutuskan program pembelajaran tanpa persetujuan siswa. Siswa harus dilihat sebagai pelanggan (costumer), yang harus diberikan pelayanan, hal ini tercermi dalam konsep Total Quaity Managemen. Jika ditinjau 
dalam konsep Islam maka guru harus memberikan pelayanan kepada murid, dengan tetap memberikan modal-modal agama dan akhlaq bagi peserta didik.

Keenam, Potensi belajar dan mengajar, paradigma baru ini menegaskan bahwa dalam dalam Standar Pembelajaran Nasional pembelajaran harus dilakukan secara interaktif, inspiratif, menyenangkan, menantang, memotivasi, keratif dan lain sebagainya, oleh sebab itu dalam penerapan dalam proses belajaran mengajar harus bergeser pada yang awalnya terpusat pada guru (teacher centris) menjadi terpusat pada murid (student centris). Dari konsep ini muncullah berbagai metode seperti Quantum Learning, Interaktive Learning, Coopratif Learning dan lain sebagainya, metode-metode tersebut berusaha untuk mengembangkan potensi yang ada dalam peserta didik. Ketujuh, dari segi lingkungan, dalam perkembangan teknologi yang terus berkembang, maka lingkungan sebagai pendukung dari proses belajar mengajar harus di sesuaikan dengan lingkungan yang ada, oleh sebab itu lembaga pendidikan pada masa sekarang harus juga dilengkapi teknologi informasi yang lengkap dan canggih dalam rangka mendukung kegiatan belajar mengajar siswa.

Kedelapan, segi sarana dan prasarana. Pada masa ini sarana prasaran bukan hanya ditentukan oleh status kepemilikan, melainkan kemungkinan untuk memanfaatkan, masyarakat sebagai salah satu sarana pendidikan mampu dimanfaatkan dengan cara memberikan skema kerja yang ada dalam masyarakat. Kesembilan, manajemen pengelolaan, paradigma baru yang harus dikembangkan dalam pengelolaan pendidikan yaitu dengan pendekatan bisnis yang bertumpu pada pelayanan kepada pelanggan seperti yang dijumpai pada konsep Total Quality Managemet. Kesepuluh, segi pendanaan, bahwa pendidikan harus dillihat sebagai alat investasi yaitu biaya yang dikeluarkan oleh peserta didik harus sebanding dengan produk dan layanan yang diterima. (Natta 2003, 147-55). Paradigma diatas secara umum bertujuan untuk membentuk pribadi yang siap dalam menghadapi bonus demografi, oleh sebab itu pendidikan Islam perlu mereformasi desain pendidikan yang sesuai dengan kebutuhan dan karakteristik model masyarakat di era bonus demografi.

Pendidikan Islam sebagai salah satu garda terdepan dalam menyiapkan manusiamanusia produktif yang siap berkompeten dalam era bonus demografi setidaknya perlu langkah-langkah dalam pelaksanaan pendidikan Islam sebagai berikut:

a. Perlu adanya pemikiran kembali konsep-konsep pendidikan Islam yang didasarkan pada asumsi dasar tentang fitrah manusia. 
b. Integrasi antara ilmu umum dan ilmu keislaman sebagai solusi dalam merekatkan jurang pemisah antara kedua ilmu tersebut.

c. Desain pendidikan untuk tercapainya sikap toleransi dalam berbagai bidang, terutama tentang perbedaan penafsiran dalam Islam dengan tanpa meninggalkan prinsip yang diyakini.

d. Mampu menumbuhkan kemandirian, etos kerja, disiplin, jujur dan swadaya dalam kehidupan.

e. Desain pendidikan yang bertujuan untuk menjawab tantangan masyarakat dan lentur terhadap perubahan zaman. (Muna, n.d., 70).

Sehingga dalam manajemen pendidikan Islam upaya yang dilakukan dalam penyiapan bonus demografi tahun 2045, adalah dengan manage pendidik sesuai dengan paradigma baru guna menjawab tantangan masa depan, yang output akhirnya adalah melahirkan manusia-manusia yang produktif dan siap kerja, dengan tetap memegang teguh prinsipprinsip dan nilai-nilai keislaman sehingga tercapai tujuan menjadi manusia yang hablum minallah, hablum minannas dan hablum minal'alam.

\section{KESIMPULAN}

Bonus demografi sebuah fenomena ledakan usia produktif harus dimanfaatkan sebaikbaiknya dalam rangka untuk membangun seluruh asepek kehidupan yang ada. Untuk menghadapi fenomena tersebut pendidikan Islam sebagai ujung tombak harus mempersiapkan dengan tepat dan cepat guna menciptakan masyarakat-masyarakat yang produktif dan tetap mempertahankan nilai-nilai ajaran Islam yang dimiliknya, salah satunya dengan membangun kembali konsep-konsep dan paradigma yang ada sesuai konteks zaman yang ada. Fungsi-fungsi manajemen dalam rangka penyiapan, pengorganisasian, pelaksanaan dan pengendalian.

\section{DAFTAR PUSTAKA}

Adnan, Mohammad. (2019). Urgensi Penerapan Manajemen Pendidikan Islam Di Era Global." Munaqasyah: Jurnal Ilmu Pendidikan Dan Pembelajaran, 1(1): 77-112. https://ejournal.stib.ac.id/index.php/mnq/article/view/10.

Andriani, Dian Sri, Agus Joko Pitoyo, and Evita Hanie Pangaribowo. (2018). "Ketidaktercapaan Bonus Demografi: Pembelajaran Dari Sumatera Barat. Populasi 26, (1) 1. https://doi.org/10.22146/jp.38685. 
Buchari, Muchtar. (1994). Ilmu Pendidikan Dan Praktik Pendidikan. Jakarta: IKIP Muammadiyah Jakarta Press.

Ekonomi, Fakultas, Jurusan Manajemen. Universitas Bangka Belitung, and Sumber Daya Manusia. n.d. "Menerapkan Nilai Islam Dalam Pembangunan Mutu Pendidikan Terkait Manajemen Sumber Daya Manusia," 47-52.

Faisal, Jusuf Amir. (1995). Reorientasi Pnedidikan Islam. Jakarta: Gema Insani Press.

Fakhriyani, Diana Vidya. (2017). Pendidikan Karakter Anak Usia Dini Sebagai Salah Satu Jawaban Dalam Mempersiapkan Generasi Muda Untuk Menggapai Bonus Demografi. Wacana Didaktika, (5)01: 76-90. https://doi.org/10.31102/wacanadidaktika.5.01.7690.

Falikhah, Nur. (2017). Bonus Demografi Peluang Dan Tantangan Bagi Indonesia. Alhadharah: Jurnal Ilmu Dakwah, (16)32. https://doi.org/10.18592/alhadharah.v16i32.1992.

Heryanah. (2015). Ageing Population Dan Bonus Demografi Kedua Di Indonesia. Populasi 23 (2): 1-16. https://jurnal.ugm.ac.id/populasi/article/view/15692/10457.

Husaini, Husaini, and Happy Fitria. (2019). Manajemen Kepemimpinan Pada Lembaga Pendidikan Islam. JMKSP: Jurnal Manajemen, Kepemimpinan, Dan Supervisi Pendidikan, 4(1). https://doi.org/10.31851/JMKSP.V4I1.2474.

Indarsih, Fajar. (2019). Implementasi Manajemen Pendidikan Islam di Pesantren. Munaqasyah: Jurnal Ilmu Pendidikan Dan Pembelajaran, 1(1): 53-68. https://ejournal.stib.ac.id/index.php/mnq/article/view/37.

Jati, Wasisto Raharjo. (2015). Bonus Demografi Sebagai Mesin Pertumbuhan Ekonomi: Jedela Peluang Atau Jendela Bencana Di Indonesia?. Populasi, 26(1): 1-19.

Konadi, Win, and Zainuddin Iba. (2008). Bonus Demografi Model Membangun Bangsa Yang Sehat Dan Bermartabat. Variasi: Majalah Ilmiah Universitas Almuslim, 2(6). http://www.jurnal.umuslim.ac.id/index.php/VRS/article/view/16/8.

Machali, Imam, and Noor Hamid. (2017). Pengantar Manajemen Pendidikan Islam. Yogyakarta: MPI Fakultas Tarbiyah UIN Sunan Kalijaga.

Maryati, Sri. (2015). Dinamika Pengangguran Terdidika: Tantangan Menuju Bonus Demografi Di Indonesia. Economic And Economic Education, 3(2): 124-36. http://ejournal.stkip-pgri-sumbar.ac.id/index.php/economica/article/view/249/641.

Muna, Nailatul. (2005). Pendidikan Islam dan Penyiapan Bonus Demografi Indonesia Tahun 2045, 67-71.

Natta, Abuddin. (2003). Manajemen Pendidikan Islam. Jakarta: Kencana.

Sarmita, I Made. (2017). Refleksi Kritis Kondisi Demografi Indonesia: Antara Bonus dan Bencana Demografi. Media Komunikasi Geografi, 18(1). https://doi.org/10.23887/mkg.v18i1.10558.

Satiti, Sonyaruri. (2019). Gerakan Ayo Sekolah di Kabupaten Bojonegoro: Peningkatan Suber Daya Manusia Melalui Pendidikan Untuk Menyonsong Bonus Demografi. Jurnal Kependudukan Indonesia, 14(1): 77-92. https://doi.org/10.14203/JKI.V14I1.351.

Sugiharto, Sugiharto, and Deny Setiawan. (2015). Pemanfaatan Bonus Demografi Melalui Peningkatan Indeks Pembangunan Manusia di Sumatera Utara. Jupiis: Jurnal Pendidikan dan Illu-Ilmu Sosial, $7(1)$ : 1-12. 
Islamic Management: Jurnal Manajemen Pendidikan Islam Doi: 10.30868/im.v4i01.833
P-ISSN: 2614-4018

E-ISSN: 2614-8846

https://doi.org/10.24114/JUPIIS.V7I1.2268.G4468. 